\begin{tabular}{|l|l|l||}
\hline \multicolumn{2}{|c|}{ PublisherInfo } \\
\hline \hline PublisherName & $:$ & BioMed Central \\
\hline \hline PublisherLocation & $:$ & London \\
\hline \hline PublisherImprintName & $:$ & BioMed Central \\
\hline \hline
\end{tabular}

\title{
Software for cell simulation
}

\begin{tabular}{|l|l|l||}
\hline \multicolumn{2}{|c|}{ ArticleInfo } \\
\hline \hline ArticleID & $:$ & 4329 \\
\hline \hline ArticleDOI & $:$ & $10.1186 /$ gb-2002-3-3-reports2011 \\
\hline \hline ArticleCitationID & $:$ & reports2011 \\
\hline \hline ArticleSequenceNumber & $:$ & 24 \\
\hline \hline ArticleCategory & $:$ & Web report \\
\hline \hline ArticleFirstPage & $:$ & 1 \\
\hline \hline ArticleLastPage & $:$ & 4 \\
\hline \hline & & RegistrationDate : 2002-1-21 \\
ArticleHistory & $:$ & Received \\
& & OnlineDate 2002-1-21 \\
\hline \hline ArticleCopyright & $:$ & BioMed Central Ltd2002-28 \\
\hline \hline ArticleGrants & $:$ & \\
\hline \hline
\end{tabular}




\begin{tabular}{|c|c|}
\hline ArticleContext & 130593333 \\
\hline
\end{tabular}

\section{Chaitanya Athale}

\section{Abstract}

The E-CELL simulation environment site is dedicated to the software tool E-CELL, which simulates biochemical interactions in cells in order to understand regulation at the level of a whole cell or organelle

\section{Content}

The E-CELL simulation environment site is dedicated to the software tool E-CELL, which simulates biochemical interactions in cells in order to understand regulation at the level of a whole cell or organelle. The primary focus of the site is software engineering of the E-CELL environment, unlike many other cell-simulation sites that focus more on biological applications, such as understanding metabolism, signaling, growth and development. The site offers developers the source code of versions 1.x and 2.x of E-CELL (3.x is currently in development), and a comprehensive collaborative platform courtesy of Bioinformatics. Org, which is a not-for-profit academia-based virtual lab that facilitates open-source software development and the exchange of bioinformatics research. Users can download the program in Linux or Windows formats, and an HTML or postscript users manual is also available. The pages discussing the latest news on E-CELL version 3.x, which is still in development, are the most interesting for developers, since they point to the vision for a 'community standard platform for at least 10-15 years'. For the users of the tool, the E-CELL project homepage will prove more useful, since it discusses modeling issues.

\section{Navigation}

Access was good at all times tested, and searching and browsing is not problematic. The site is mainly organized into three modules (for the developer, user and general audience), and each module has a clear but different structure. As the design of the modules differs, moving within a module is convenient, but once one has crossed over from one to another, getting back can be inconvenient. The section devoted to the E-CELL development and user forums is full of dynamic sections where comments can be directly added to the online material. Other parts of the user forums are also convenient to search because of the use of the MoinMoin-based script with features like indices based on title, words and recent change, full search facilities and page views showing deletions and additions. The literature on the site can be 
downloaded in HTML and postscript formats. E-CELL software versions 1.x and 2.x are available for download under a General Public License (GPL), with source code as well as the model descriptions.

\section{Reporter's comments}

\section{Timeliness}

The site was last updated on 11 November 2001.

\section{Best feature}

The multitude of features on offer for collaboration and exchanges between and within the developer and user communities is by far the best aspect of the site.

\section{Worst feature}

A lack of discussion about results obtained with the stable E-CELL version (version 1.x ) is the biggest deficiency.

\section{Wish list}

Discussions about results obtained with E-CELL and a list of related and similar sites.

\section{Related websites}

The older E-CELL site hosts a user manual, literature, models, a user mailing-list and information about Masaru Tomita's group, who created E-CELL. This site has links to the lab in which the E-CELL project started - the Bioinformatics Laboratory at Keio University - and the Institute for Advanced Biosciences, Keio University, where further work on the project, including the application of E-CELL to optimal industrial-microbe design, is planned. Tools similar to E-CELL are also available at the websites 
for GEPASI, a biochemical network simulator, and GENESIS, a tool for simulating neural genetic and physiological networks on both the single-cell and systems scale.

\section{Table of links}

E-Cell simulation environment

Bioinformatics.Org

MoinMoin-based script

The older E-CELL site

Bioinformatics Laboratory at Keio University

Institute for Advanced Biosciences, Keio University

GEPASI

GENESIS

\section{References}

1. E-Cell simulation environment.

This PDF file was created after publication. 